\title{
An unorthodox Geopolitical-epidemiological approach to address the COVID-19 global vaccination
}

distribution

\section{Federico Gerardo de Cosio ${ }^{*}$, Beatriz Diaz-Apodaca ${ }^{2}$, Hector Ojeda-Casares ${ }^{3}$, Lorely Ambriz $^{4}$}

${ }^{1}$ Visiting and Research Professor, Global Health Intelligence to the Dean's Office, College of Health Science, University of Texas at El Paso, ElPaso, 500 W. University Ave. El Paso, Texas 79912, USA

${ }^{2}$ General Coordinator, Research and Graduate Studies Universidad Autonoma de Ciudad Juarez, Manuel Diaz H. No. 518-B Zona Pronaf Condominio, 32315 Cd. Juarez, Chihuahua, Mexico.

${ }^{3}$ Genetics, Health Manager, Proyecto Esperanza, Ave. Franciso de Miranda, Edificio Menegrande, Caracas, Distritio Federal Venezuela. ${ }^{4}$ Head Librarian/Associate Professor, El Paso Community College, 6701 S. Desert Blvd. El Paso, Texas 79932, USA

*Corresponding Author: Federico Gerardo de Cosio, Visiting and Research Professor, Global Health Intelligence to the Dean's Office, College of Health Science, University of Texas at El Paso, El Paso, 500 W. University Ave. El Paso, Texas 79912, USA

Received date: 15 May 2021; Accepted date: 24 May 2021; Published date: 25 May 2021

Citation: de Cosio FG, Diaz-Apodaca B, Ojeda-Casares H, Ambriz L. An unorthodox Geopolitical-epidemiological approach to address theCOVID-19 global vaccination distribution. J Comm Med and Pub Health Rep 2(4): https://doi.org/10.38207/jcmphr20210061

Copyright: ( 2021 Federico Gerardo de Cosio. This is an open-access article distributed under the terms of the Creative Commons Attribution License, which permits unrestricted use, distribution, and reproduction in any medium, provided the original author and source are credited.

\begin{abstract}
Besides the COVID-19 pandemic, the world is also facing a COVID-19 vaccination turmoil. At present, COVID-19 vaccines are available in limited quantities, and when they are available, they are already reserved for high-income countries that have established bilateral agreements with vaccine pharmaceutical manufactures. The dilemma about vaccine quantities and accessibility has reached critical inefficiency levels, as access to them is inequitable as some countries and pharmaceutical companies have prioritized bilateral agreements. There is a "moral failure," leaving behind the most vulnerable population around the world. Consequently, the rich and the poor must work together through a collaborative effort to set priorities based on a geopolitical-epidemiological approach, which first identifies countries that are at the highest risk and driving the burden of the pandemic. Secondly, decisions are made based on epidemiological evidence to support decision- and policymakers.

Standardized mortality ratios (SMR) should be used to prioritize COVID-19 vaccine access because of the limited number of them worldwide, leaving at this point most countries of the world (developed and developing) with small numbers of vaccines that hardly will contribute to control, mitigate or suppress the pandemic, that is why those limited number of vaccines should be targeted to those geographic and the highrisk group where the impact will be higher.

As of March 13, 2021, the estimated number of doses was 345.2 million vaccine doses (of which $29.3 \%$ were in the United States) representing $2.6 \%$ of the total world population, with five countries (United States, India, The United Kingdom, China, and Russia) accounting for $60.9 \%$ $(210,320,000)$ of all vaccine doses administered globally. Together these five countries account for $43.2 \%$ of the total population of the world. We identified the 30 countries with the highest SMR and distributed them according to each WHO region. These countries should be prioritized in the distribution of vaccines. Most countries of the African, South-East and Western-Pacific Regions (from 240 in South Africa-0.39 in Thailand) have the lowest SMR ranging. Whereas, the Americas (from 456 in the United States-271.88 in Puerto Rico) and European Regions (from 736 in San Marino-411in France) have SMRs that have over-burned the operational capacity of their health systems.

SMR should be used to prioritize COVID-19 vaccine access because of the limited number of them worldwide, leaving at this point most countries of the world (developed and developing) with small numbers of vaccines that hardly will contribute to control, mitigate or suppress the pandemic, that is why those limited number of vaccines should be targeted to those geographic and high-risk groups where the impact will be higher.
\end{abstract}

Keywords: MeSH Description COVID-19, Vaccines/supply \& distribution, Pandemics, Global Health, Public Health, Diplomacy, Stakeholder Participation

\section{Introduction}

In addition to the COVID-19 pandemic crisis, the SARS-CoV-2 virus (COVID-19 virus name) continues challenging the world with its frequent mutations and increasing the likelihood that one of these mutations may lead to a virus vaccine escape; the world is also facing a COVID-19 vaccination turmoil.

At present, COVID-19 vaccines are available in limited quantities and, when they are available, they are already reserved for highincome countries that have established bilateral agreements with 
vaccine pharmaceutical manufacture. The scarcity of vaccines is influencing the geographical dimension of country interactions, their socioeconomic determinants, and the implementation of foreign policies within the scope to put before anything else the national interest or geopolitics and, whenever possible establish ageopolitical alliance to access vaccines. According to Foreign Affairs magazine [1], between 80-100 \% of the vaccines produced by Pfizer/BioNTech, Moderna, and Johnson and Johnson have already been reserved for a handful of countries or economic blocks (e.g., the United States, Japan, Australia, Canada, and the European Union). The amounts of vaccines these countries have reserved can vaccinate more than once their entire populations. Hopefully, once these countries notice that they could share their COVID-19 vaccine excesses, they will do it through a globally coordinated mechanism such as the World Health Organization (WHO) to maximize the positive impact of the COVID19 vaccines. Some middle-income countries have also made bilateral agreements with vaccine manufacturers (e.g., Mexico, Argentina, Brazil, and Chile). With the inclusion of new platforms such as Sputnik 4, Sinopharm, CanSino, AstraZeneca, and others thevaccine supply is expected to increase, but very slow, as the existing production capacity is under development. However, the number of vaccines they are getting is small compared to what they need to cover their need.

Furthermore, the dilemma about vaccine quantities and accessibility has reached critical inefficiency levels as access to them are inequitable as some countries and pharmaceutical have prioritized bilateral agreements. In this regard, Dr. Tedros Adhanom Ghebreyesus, director-general of the WHO has alleged about the "mefirst approach" "I need to be blunt: The world is on the brink of a catastrophic moral failure, and the price of this failure will be paid with lives and livelihoods in the world's poorest countries" [2]. Even for some of the wealthiest countries, the 'me-first approach' is unreachable; currently, there are not enough vaccines to cover their own needs. Consequently, the rich and the poor must work together through a collaborative effort to set priorities based on a geopoliticalepidemiological approach, which first identifies countries at the highest risk and is driving the burden of the pandemic Secondly, decisions should be made based on epidemiological evidence to support decision- and policymakers.

In 2020, the WHO Member States passed a Resolution that recognizes that the COVID-19 vaccine is a public good. Such access to the vaccine should be made at no cost, [3] but this is not enough, as without the allocation of the financial, distribution, logistical, cold chain network, and human resources that are needed to vaccinate millions of people, the Resolution becomes a goodwill statement. Not every country has the resources necessary to carry out a vaccination endeavor of this magnitude and complexity. Technical and financial support is required to strengthen many low-income countries' capacity. That is why a COVID-19 vaccine coordination effort is needed to assess their capabilities to identify the most critical needs. This is not the time to waste resources with bilateral and political agreements as the world are not just in the middle of a health crisis but also of an economic one, and an unforeseeable predicament associated with the collateral non-COVID-19 health effects that have resulted because health care services we reoriented to provide care to COVID-19 cases, consequently, resulting in an increase in maternal and child mortality, routine vaccination coverage decreasing, HIV and TB on the rise, mental health at its worse, and life expectancy gains falling. The collateral non-COVID-19 effects are expected to arise several years after the end of the pandemic. Before the pandemic reaches catastrophic levels. The WHO director-general said, the global community needs to establish a COVID-19 coordination mechanism that supports the collaborative efforts of sharing vaccines doses and any other supplies needed to implement vaccination campaigns, or even more, as the Global Alliance on Vaccines Initiative (GAVI) suggests that the global community should createa cost-sharing effort to cover up vaccine doses, [4] meaning that the receiving country, donor and vaccine manufacturers contribute in making more equitable the burden of the vaccination campaigns.

Regardless of their income level, high-, middle- and low-income countries have joined the COVAX initiative, coordinated by GAVI, and supported by WHO and UNICEF to increase their chances to access vaccines at an equitable cost or provide financial support for the procurement of vaccines. The COVAX initiative aims to make available at least 2 billion doses of COVID-19 vaccine to lowermiddle- and low-income countries (representing only $20 \%$ of their population, which is not enough to reach the 65-70\% herd immunity threshold), so more equitable access to the vaccine can be achieved. Unfortunately, the vaccines available through COVAX at this point is minimal, as well as COVAX has severe financial constraints to purchase the needed vaccines for lower-middle- and low-income countries participating in this initiative $[\mathbf{1}, \mathbf{3}]$. However, COVAX depends on donors' funds, which are limited as they are also struggling to access their vaccines and are facing an economic crisis. Therefore, most less financially advantageous countries willbe left at the end of the list as they will have to rely on loans (hopefullynot depredatory), vaccine diplomacy, or donor-funded mechanisms. [3] Other countries like Brazil, India, Argentina, and Mexico have reached agreements with AstraZeneca [1] to manufacture vaccines; thus, giving them priority access to vaccines that otherwise would not have been possible to have them. At this point, governments are competing to have access to the limited number of doses of the COVID-19 vaccines in the market, vaccines manufactures are giving preference to satisfy bilateral agreements (leaving COVAX in second place), and vaccine producing countries are putting nationalism and restricted access to the market for COVID-19 vaccines to meet their demand first, which is generating unequal access to vaccines, [5] as well as for most countries, the control of the pandemic is a national 
security issue that cannot be neglected. Furthermore, although COVAX vaccine distribution has begun, it will not be exempt from inequities and ethical questions about how they decided the amounts of vaccines for each country. For instance, middle-income countries have almost half of the total cases of COVID-19 globally. Still, these countries have access to only $17 \%$ of the global vaccines (Chinaand upper-middle-income are excluded). [6] Although low-income countries have $0.5 \%$ of worldwide cases, they will have better chances of accessing vaccines at an affordable cost as they met the preferential criteria for free vaccines. For instance, 92 low-and lowermiddle-income countries were eligible for free vaccines through COVAX. [6] The remaining middle-income countries will have to search for financial resources to vaccinate their populations, as they did not qualify for free vaccines from COVAX.

Vaccine manufactures are struggling to maintain a steady increasing production and are stressed to satisfy bilateral agreements, and subsequently, multilateral agreements supply demands. Even the United States initiative of 150 million in 100 days of the new administration was lagging as there are not enough vaccines available. However, recently, the United States is catching up with its target, including a pledge from President Joe Biden on March 10, 2021, that by May 1, 2021, all adults will be eligible for vaccines. [7] Many countries are experiencing delays in vaccine deliveries (Argentina, Canada, Mexico, and COVAX) because there is not enough production or manufactures, and COVID-19 vaccination programs face logistical problems in delivering the vaccines on time. It is expected that in time the production of vaccines will increase, and more vaccine platforms enter the market, and pharmaceutical vaccine manufacturers will have solved production challenges. Possibly intellectual rights agreement with multiple countries that canproduce their vaccines will be in place. The United States recently announced its support for waiving intellectual property protection for COVID-19 vaccines, including its participation in the negotiations that will take place at the World Trade Organization deliberations. [8]

Until the production increases, the world will have to wait. Hopefully, the SARS-CoV-2 virus will not mutate to a new strain with a vaccine escape capacity, putting the world at its mercy and at a higher risk of prolonging this pandemic and its health, social and economic crisis. In contrast, the existing vaccines are adapted to respond to the new COVID-19 challenges. Although Pfizer/BioNTech, Moderna and Johnson and Johnson's vaccines have shown to be effective against new virus variants, Astra/Zeneca has withdrawn their vaccine from South Africa as the immunity induced in the dominant South Africa

\section{Methods}

As mentioned above, to assess the impact of COVID-19, the global community and countries are counting cases and deaths, leaving aside epidemiological methods beyond numbers or crude morbidity and mortality rates. Standardized mortality rates and standardized strain variant did not protect the population. [9] The continuous mutation of SARS-CoV-2 can create new variants that can escape the vaccines' induced immunity, not allowing the protection providedby antibodies. So, countries must be prepared to address this situation. Although, luckily, the adaptability of new vaccine technologies will allow a rapid response to these problems.

Currently, Moderna, Pfizer/BioNTech and Astrazeneca assess the possibility of adding a third dose to the COVID-19 vaccine scheme to include the new variants that have an escape vaccine immunity for those individuals that have already received the vaccine.

Regardless of the already established bilateral agreement of many countries, the COVID-19 Vaccine Global Coordination will ensure that vaccines that are not part of bilateral agreements and the excess vaccines from the bilateral agreements are distributed in those geographic areas where they will have the highest impact, based mainly on the severity of the pandemic. One suggested approach to do it is by measuring the severity of the mortality (morbidity or any other risk can be added if deemed appropriate) using standardized mortality ratios (SMR) as proposed in this article [10]. The geopolitical-epidemiological approach in the early vaccination stage can help identify priority high-risk and vulnerable populations and geographic areas that may render the highest impact to control and contain the COVID-19 pandemic, or as ethicists have suggested, there should be a "fair priority model" for the allocation of vaccines "where vaccine harm-reducing powers are most urgently needed." [6]

To vaccinate millions of people in a relatively short period, the use of bold and proactive approaches is required instead of regularly use in many countries, which are based on passive or semi-passive vaccination outreach, where the program waits for the people to reach the vaccine, rather than programs outreach the community. As soon as possible, national programs must move to direct work in the communities without waiting for the communities to reach them, as is traditionally the case. Proactive vaccination strategies pay off in a relatively short time. This strategy has proved that this process is helpful to control preventable diseases by vaccination or any other infectious disease outbreak faster. It is also crucial to consider, given the limited number of vaccines, that the COVID-19 vaccine coordination should distribute enough vaccines to cover first responders all over the world, regardless of the SMR they have a while, implementing the geopolitical-epidemiological approach to reach the high-risk group by high impact geographic area, to maximize the use of vaccines.

mortality ratios (SMR) can contribute to identifying and setting priorities. They consider population structures, remove the effects of different population compositions and deaths, and provide useful data that can help make decisions. [11] between and within countries. The 
use of crude rates does not allow comparison between countries and populations of the same country. They do not consider the different structure of population age or variation in time.

In this study, SMR was used as an indirect method to study the impact of the COVID-19 pandemic in each country and facilitate the identification and selection of priority countries for vaccine distribution if there is a shortage of vaccines (Table 1).

To identify priority countries based on SMRs, we used aggregated accumulative deaths and cases reported to the WHO up to January 18, 2021, to calculate SMR ratios for the 2020 COVID-19 pandemic. Population estimates were obtained from the United Nations Population Division [12] for each WHO member state. It is anticipated that since data reports from the WHO [13] are lagging, the January 18, 2021 period's selection increases the likelihood of including a higher percentage of cases and deaths in the year 2020.

\section{Results}

In 2020, there were about 93,805,612 COVID-19 cases and 2,026,093 deaths worldwide, with a corresponding crude mortality rate per 100,000 of 1203.44 and 25.99, respectively. Mortality crude rates in all countries are substantially lower than SMR for fatalities (Table 1). Our World in Data Webpage Data Explorer about COVID-19 vaccination data [14] that tracks the number of existing vaccine doses by country has reported that between February 23 and March 13, 2021, the number of doses increased from 61,646,882 to 345.2 million doses of vaccines. (of which $29.3 \%$ were in the United States) in less than a month, representing $0.79 \%$ and $2.6 \%$ respectively ofthe total world population (Table 1) By March 13, five countries (United States, India, The United Kingdom, China, and Russia) accounted for $60.9 \%(210,320,000)$ of all vaccine doses administered globally. Together these five countries account for $43.2 \%$ of the total population of the world. It appears that the quantity of vaccines available to all countries of the world is like giving vaccine crumbs to them since there are not enough vaccines even to cover first line responders, and much less the high-risk groups of said countries' populations.

With the proposed methodology, we identified 30 countries that should be prioritized in distributing vaccines according to each region. Table 1 provides the SMR for countries with the highest SMRs. Although Table 1 includes high-income countries with bilateral agreements with vaccine manufacturers or vaccine producers, they should be excluded from the priority list as they have preferential access to the COVID-19 vaccines. China and Russia are
Once the SMR we estimated, Confidence Intervals (CI) were obtained and classified in three groups to identify priority countries by WHO Region:

- If lower CI was above 100 , it is considered a high priority, meaning that health services' operational capacity is over-burned,with expected deaths lower than observed. Countries in this groupare assigned to group 3.

- If lower CI was below 100 and upper CI was above 100, its operational capacity is acceptable, with expected deaths and observed deaths within the same range. Countries in this group are assigned to group 2.

- If upper CI is below 100, it is considered low priority, meaning the operation capacity is not stressed and a higher number of expected deaths than observed. Countries in this group are assigned to group 1.

not listed as their SMRs are 1.29 and 174.09, and both are vaccine producers. The recommended priority countries are Africa: South Africa, Eswatini, Cape Verde, Mayotte, Namibia; Americas: Peru, Panama, Mexico, Brazil, Argentina, Colombia, Puerto Rico; Eastern Mediterranean: Tunisia, Jordan, Palestine, Iraq, Oman; Europe: San Marino, Belgium, Slovenia, Bosnia and Herzegovina, Czechia; South-East Asia: Indonesia, Maldives, Nepal, Myanmar, Bangladesh; Western Pacific: Guam, French Polynesia, Philippines, Australia, and the Northern Mariana Islands.

As for the number of vaccine doses, the Region of Africa is way lagging, with only $0.06 \%(224,058)$ of the total vaccine doses; however, according to Table 1, except for South Africa and Eswatini have low SMR, meaning that their health services capacity has not been stressed yet. The Region of the Americas leads the access to vaccine doses with 116,063,229 vaccine doses, with the United States accounting for $87 \%$ of all doses, followed by Chile. In general, the Americas has a lower SMR than many European countries. Despite having very high SMR the European Region has only administered $37,276,490$, representing 10.7 of the vaccine doses. South-East Asia's SMR is low, with most vaccine doses administered in India, followed by Indonesia and Bangladesh. All countries of the Americas and European Region has a higher number of observed deaths than expected (Table 1), that is their lower CI will be above 100. All countries in South East Asia have a higher number of expected deaths than observed, meaning higher CI was lower than 100.

Table 1: Countries Prioritized by World Health Organization Region* 


\begin{tabular}{|c|c|c|c|c|c|c|c|c|c|c|c|c|}
\hline $\begin{array}{l}\text { Region / } \\
\text { Country }\end{array}$ & $\begin{array}{l}\text { Numbei } \\
\text { Vaccine }\end{array}$ & $\begin{array}{l}\text { r of } \\
\text { es Applied }{ }^{1}\end{array}$ & $\begin{array}{l}\text { Country } \\
\text { Population- } \\
2020^{2}[11]\end{array}$ & $\begin{array}{l}\text { Cases - } \\
\text { cumula } \\
\text { tive } \\
\text { total }^{3} \\
{[12]}\end{array}$ & $\begin{array}{l}\text { Expected } \\
\text { Deaths }^{4}\end{array}$ & $\begin{array}{l}\text { Obser } \\
\text { Deaths } \\
{[12]}\end{array}$ & ed & $\begin{array}{l}\text { COVID-19 } \\
\text { Mortality } \\
\text { Rates }^{4}\end{array}$ & $\begin{array}{l}\text { SMR- } \\
\text { Death }^{4}\end{array}$ & $\begin{array}{l}95 \% \\
\text { CI } \\
\text { Lower } \\
\text { Limit } \\
\text { SMR } \\
\text { Deaths }\end{array}$ & \begin{tabular}{|l|} 
\\
$95 \%$ CI \\
UpperLimit \\
SMR \\
Deaths ${ }^{4}$
\end{tabular} & $\begin{array}{l}\text { Priori } \\
\text { ty } \\
\text { Level } \\
\text { for } \\
\text { Death } \\
s^{4}\end{array}$ \\
\hline & $\begin{array}{l}\text { As of } \\
\text { January23 }\end{array}$ & As of March 13 & & \multicolumn{2}{|c|}{$\begin{array}{l}\text { As of JanuaryAs of January23 } \\
23\end{array}$} & $\begin{array}{l}\text { As of } \\
\text { January23 }\end{array}$ & \multicolumn{2}{|c|}{$\begin{array}{l}\text { As of MarchAs of January } 23 \\
13\end{array}$} & \multicolumn{4}{|l|}{$\begin{array}{l}\text { As of } \\
\text { January23 }\end{array}$} \\
\hline \multicolumn{13}{|l|}{ Africa } \\
\hline $\begin{array}{l}\text { South } \\
\text { Africa }\end{array}$ & & 145,215 & $59,308,690$ & $\begin{array}{l}1,337,9 \\
26\end{array}$ & 15,416 & $\begin{array}{l}37,10 \\
5\end{array}$ & 51,17 & 62.56 & 240.6 & 238.24 & 243.14 & 3 \\
\hline Eswatini & & & $1,160,164$ & 12,944 & 302 & 376 & 659 & 32.41 & $\begin{array}{l}124.6 \\
8\end{array}$ & 112.08 & 137.29 & 3 \\
\hline Mayotte & & & 272,813 & 6,611 & 71 & 58 & 129 & 21.26 & 81.79 & 60.74 & 102.84 & 2 \\
\hline $\begin{array}{l}\text { Cape } \\
\text { Verde }\end{array}$ & & & 555,988 & 12,993 & 145 & 119 & 54 & 21.4 & 82.34 & 67.55 & 97.14 & 1 \\
\hline Namibia & & & $2,540,916$ & 30,363 & 660 & 285 & 456 & 11.22 & 43.15 & 38.14 & 48.16 & 1 \\
\hline Mauritiu & & 3,843 & $4,649,660$ & 16,039 & 1,209 & 402 & 442 & 8.65 & 33.26 & 30.01 & 36.51 & 1 \\
\hline $\begin{array}{l}\text { Sao Tome } \\
\text { and } \\
\text { Principe }\end{array}$ & & & 219,161 & 1,142 & 57 & 17 & 32 & 7.76 & 29.84 & 15.66 & 44.03 & 1 \\
\hline Algeria & & 75,000 & $43,851,043$ & $\begin{array}{l}103,83 \\
3\end{array}$ & 11,398 & 2,841 & 3 & 6.48 & 24.93 & 24.01 & 25.84 & 1 \\
\hline $\begin{array}{l}\text { Equatori } \\
\text { al Guinea }\end{array}$ & & & $1,402,985$ & 5,356 & 365 & 86 & 98 & 6.13 & 23.58 & 18.6 & 28.57 & 1 \\
\hline Gambia & & & $2,416,664$ & 3,910 & 628 & 127 & 153 & 5.26 & 20.22 & 16.7 & 23.73 & 1 \\
\hline \multicolumn{13}{|l|}{ Americas } \\
\hline $\begin{array}{l}\text { United } \\
\text { States }\end{array}$ & $\begin{array}{l}10,91 \\
1,000\end{array}$ & $\begin{array}{l}101,130 \\
000\end{array}$ & $331,002,647$ & $\begin{array}{l}23,556 \\
676\end{array}$ & 86,037 & $\begin{array}{l}392,6 \\
41\end{array}$ & $\begin{array}{l}527,0 \\
68\end{array}$ & 118.62 & $\begin{array}{l}456.3 \\
6\end{array}$ & 454.93 & 457.79 & 3 \\
\hline$\overline{\text { Peru }}$ & & 449,634 & $32,971,846$ & $\begin{array}{l}1,060,5 \\
67\end{array}$ & 8,570 & $\begin{array}{l}38,77 \\
0\end{array}$ & $\begin{array}{l}48,48 \\
4\end{array}$ & 117.59 & $\begin{array}{l}452.3 \\
7\end{array}$ & 447.87 & 456.88 & 3 \\
\hline Panama & 5,081 & 245,177 & $4,314,768$ & 296,26 & 1,122 & 4,738 & 5,972 & 109.81 & $\begin{array}{l}422.4 \\
6\end{array}$ & 410.43 & 434.49 & 3 \\
\hline Mexico & $\begin{array}{l}614,8 \\
08\end{array}$ & $\begin{array}{l}4,001,00 \\
0\end{array}$ & $128,932,753$ & $\begin{array}{l}1,630,2 \\
58\end{array}$ & 33,513 & $\begin{array}{l}140,2 \\
41\end{array}$ & $\begin{array}{l}193,1 \\
42\end{array}$ & 108.77 & $\begin{array}{l}418.4 \\
6\end{array}$ & 416.27 & 420.65 & 3 \\
\hline Brazil & $\begin{array}{l}537,7 \\
74\end{array}$ & 336,660 & $212,559,409$ & $\begin{array}{l}8,455,0 \\
59\end{array}$ & 55,250 & $\begin{array}{l}209,2 \\
96\end{array}$ & $\begin{array}{l}272,8 \\
89\end{array}$ & 98.46 & $\begin{array}{l}378.8 \\
1\end{array}$ & 377.19 & 380.44 & $\sqrt{3}$ \\
\hline Argentin & $\begin{array}{l}288,0 \\
64\end{array}$ & $2,100,00$ & $45,195,777$ & $\begin{array}{l}1,791,9 \\
79\end{array}$ & 11,748 & $\begin{array}{l}45,29 \\
5\end{array}$ & 83,57 & 100.22 & $\begin{array}{l}385.5 \\
7\end{array}$ & 382.01 & 389.12 & 3 \\
\hline Colombi & & 589,208 & $50,882,884$ & $\begin{array}{l}1,891,0 \\
34\end{array}$ & 13,226 & $\begin{array}{l}48,25 \\
6\end{array}$ & $\begin{array}{l}60,85 \\
8\end{array}$ & 94.84 & $\begin{array}{l}364.8 \\
6\end{array}$ & 361.6 & 368.11 & 3 \\
\hline Chile & $\begin{array}{l}63,04 \\
7\end{array}$ & $\begin{array}{l}6,520,00 \\
0\end{array}$ & $19,116,209$ & $\begin{array}{l}669,83 \\
2\end{array}$ & 4,969 & $\begin{array}{l}17,47 \\
7\end{array}$ & $\begin{array}{l}21,45 \\
1\end{array}$ & 91.43 & $\begin{array}{l}351.7 \\
3\end{array}$ & 346.52 & 356.95 & 3 \\
\hline Bolivia & & 137,150 & $11,673,029$ & $\begin{array}{l}185,68 \\
0\end{array}$ & 3,034 & 9,596 & $\begin{array}{l}11,90 \\
3\end{array}$ & 82.21 & $\begin{array}{l}316.2 \\
7\end{array}$ & 309.94 & 322.59 & 3 \\
\hline
\end{tabular}




\begin{tabular}{|l|l|l|l|l|l|l|l|l|l|l|l|l|l|}
\hline Ecuador & 108 & 106,228 & $17,643,060$ & 230,80 & 4,586 & 14,31 & 16,19 & 81.14 & 312.1 & 307.06 & 317.29 & 3 \\
\hline Belize & & 7,444 & 397,621 & 11,529 & 103 & 281 & 316 & 70.67 & 271.8 & 240.09 & 303.67 & 3 \\
\hline $\begin{array}{l}\text { Puerto } \\
\text { Rico }\end{array}$ & 9,873 & 440,728 & $2,860,840$ & 87,372 & 744 & 1,703 & 2,073 & 59.53 & 229.0 & 218.14 & 239.89 & 3 \\
\hline
\end{tabular}

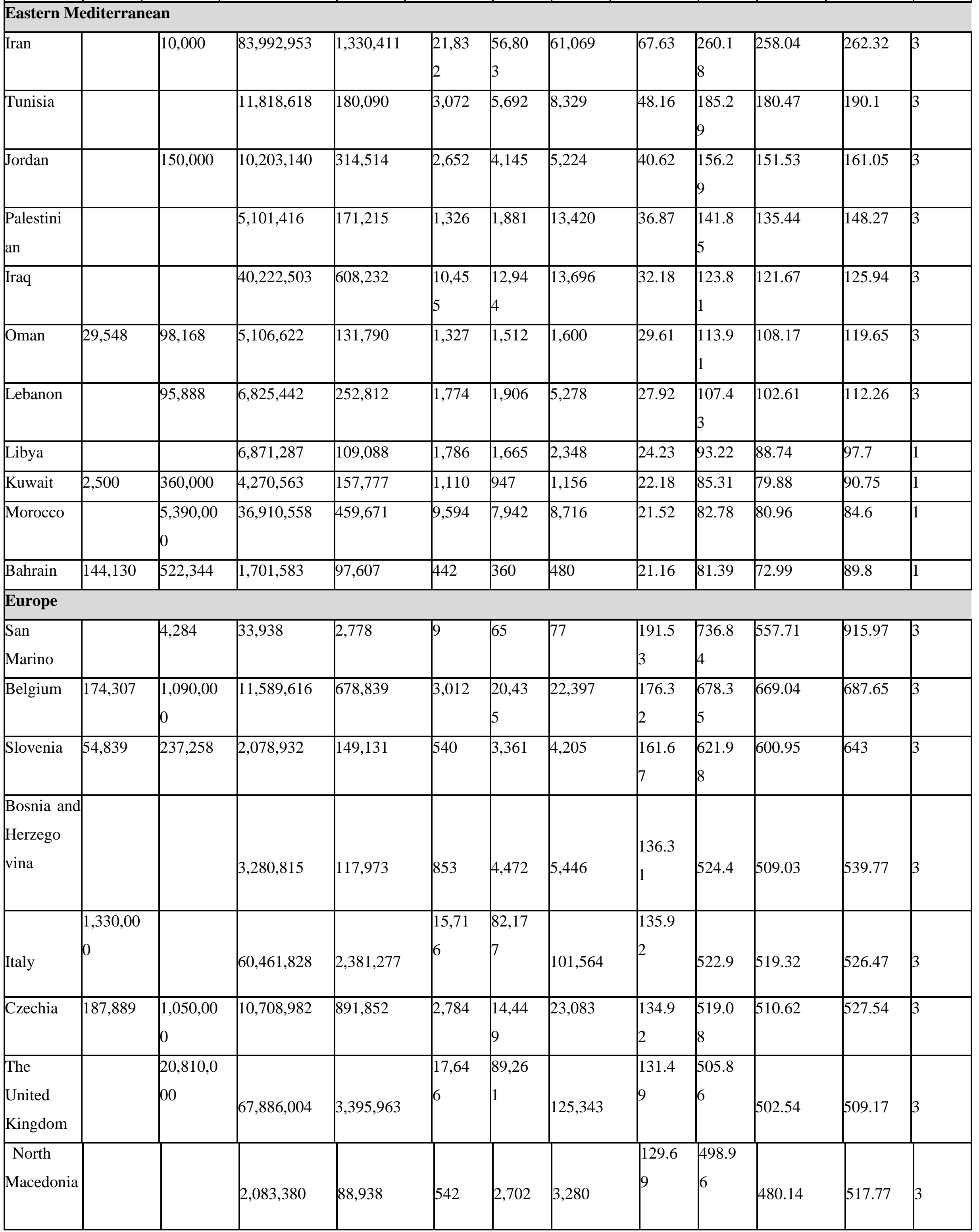




\begin{tabular}{|l|l|l|l|l|l|l|l|l|l|l|l|l|}
\hline Bulgaria & 26,101 & 336,660 & $6,948,445$ & 211,813 & 1,806 & 8,483 & 11,196 & $\begin{array}{l}122.0 \\
8\end{array}$ & $\begin{array}{l}469.6 \\
9\end{array}$ & 459.69 & 479.68 & 3 \\
\hline $\begin{array}{l}\text { Montene } \\
\text { gro }\end{array}$ & & 3,374 & 628,062 & 55,561 & 163 & 745 & 1,113 & 118.6 & 456.3 & 423.58 & 489.12 & 3 \\
\hline Hungary & 150,129 & $1,670,00$ & $9,660,350$ & 352,703 & 2,511 & 11,40 & 16,790 & 118.1 & 454.3 & 446.02 & 462.7 & 3 \\
\hline Andorra & 0 & & & & & & & & & & & \\
\hline Spain & $1,170,00$ & $5,350,00$ & $46,754,783$ & $2,211,967$ & 12,15 & 53,07 & 72,258 & 113.5 & 436.7 & 433.04 & 440.48 & 3 \\
\hline France & 963,139 & $6,720,00$ & $65,273,512$ & $2,863,613$ & 16,96 & 69,89 & 89,632 & 107.0 & 411.9 & 408.9 & 415.01 & 3 \\
\hline
\end{tabular}

\section{South-East Asia}

\begin{tabular}{|c|c|c|c|c|c|c|c|c|c|c|c|c|}
\hline$\overline{\text { India }}$ & $\begin{array}{l}1,390,00 \\
0\end{array}$ & $\begin{array}{l}28,220,0 \\
00\end{array}$ & $\begin{array}{l}1,380,004,3 \\
85\end{array}$ & $10,571,773$ & $\begin{array}{l}358,7 \\
03\end{array}$ & $\begin{array}{l}152,4 \\
19\end{array}$ & 158,446 & 11.04 & 42.49 & 42.28 & 42.71 & T1 \\
\hline Indonesi & 132,000 & $\begin{array}{l}5,110,00 \\
0\end{array}$ & $273,523,621$ & 907,929 & $\begin{array}{l}71,09 \\
7\end{array}$ & 25,98 & 38,229 & 9.5 & 36.55 & 36.11 & 37 & 1 \\
\hline Maldives & & 188,436 & 540,542 & 14,513 & 141 & 49 & 64 & 9.06 & 34.87 & 25.11 & 44.64 & 1 \\
\hline$\overline{\text { Nepal }}$ & & 402,264 & $29,136,808$ & 267,322 & 7,573 & 1,959 & 3,012 & 6.72 & 25.87 & 24.72 & 27.01 & 1 \\
\hline Myanma & & 103,142 & $54,409,794$ & 134,318 & $\begin{array}{l}14,14 \\
3\end{array}$ & 2,955 & 3,201 & 5.43 & 20.89 & 20.14 & 21.65 & 1 \\
\hline $\begin{array}{l}\text { Banglade } \\
\text { sh }\end{array}$ & & $\begin{array}{l}4,220,00 \\
0\end{array}$ & $164,689,383$ & 527,632 & $\begin{array}{l}42,80 \\
8\end{array}$ & 7,906 & 8,515 & 4.8 & 18.47 & 18.06 & 18.88 & 1 \\
\hline $\begin{array}{l}\text { Sri } \\
\text { Lanka }\end{array}$ & & 760,765 & $21,413,250$ & 53,062 & 5,566 & 264 & 525 & 1.23 & 4.74 & 4.17 & 5.32 & 1 \\
\hline Bhutan & & & 771,612 & 842 & 201 & 1 & 1 & 0.13 & 0.5 & -0.48 & 1.48 & 1 \\
\hline Thailand & & 33,621 & $69,799,978$ & 12,423 & $\begin{array}{l}18,14 \\
3\end{array}$ & 70 & 86 & 0.1 & 0.39 & 0.3 & 0.48 & 1 \\
\hline $\begin{array}{l}\text { Democra tic } \\
\text { People's } \\
\text { Republic of } \\
\text { Korea }\end{array}$ & & & $25,778,815$ & 0 & 6,701 & 0 & 0 & 0 & 0 & & & 1 \\
\hline $\begin{array}{l}\text { Timor- } \\
\text { Leste }\end{array}$ & & & $1,318,442$ & 52 & 343 & 0 & 0 & 0 & 0 & & & 1 \\
\hline \multicolumn{13}{|c|}{ Western Pacific } \\
\hline Guam & & & 168,783 & 7,286 & 44 & 127 & 133 & 75.24 & $\begin{array}{l}289.4 \\
8\end{array}$ & 239.13 & 339.83 & $\sqrt{3}$ \\
\hline $\begin{array}{l}\text { French } \\
\text { Polynesia }\end{array}$ & & & 280,904 & 17,635 & 73 & 126 & 141 & 44.86 & 172.5 & 142.44 & 202.7 & 3 \\
\hline $\begin{array}{l}\text { Philippin } \\
\text { es }\end{array}$ & & 114,500 & $109,581,085$ & 500,577 & $\begin{array}{l}28,48 \\
3\end{array}$ & 9,895 & 12,694 & 9.03 & 34.74 & 34.06 & 35.42 & 1 \\
\hline Australia & & 135,103 & $25,499,881$ & 28,708 & 6,628 & 909 & 909 & 3.56 & 13.71 & 12.82 & 14.61 & 1 \\
\hline $\begin{array}{l}\text { Northern } \\
\text { Mariana } \\
\text { Islands }\end{array}$ & & & 57,557 & 129 & 15 & 2 & 2 & 3.47 & 13.37 & -5.16 & 31.9 & ] \\
\hline
\end{tabular}




\begin{tabular}{|l|l|l|l|l|l|l|l|l|l|l|l|l|l|}
\hline $\begin{array}{l}\text { Republic } \\
\text { of Korea }\end{array}$ & & & $1,269,183$ & 72,729 & $\begin{array}{l}13,32 \\
6\end{array}$ & 1,264 & 1,667 & 2.47 & 9.48 & 8.96 & 10.01 & 1 \\
\hline Malaysia & & $2,754,28$ & $32,365,998$ & 158,434 & 8,413 & 601 & 1,203 & 1.86 & 7.14 & 6.57 & 7.71 & 1 \\
\hline $\begin{array}{l}\text { Brunei } \\
\text { Darussal } \\
\text { am }\end{array}$ & & & & & & & & & & & & & \\
\hline $\begin{array}{l}\text { New } \\
\text { Zealand }\end{array}$ & & 30,061 & $4,822,233$ & 1,906 & 1,253 & 25 & 26 & 0.52 & 1.99 & 1.21 & 2.78 & 1 \\
\hline $\begin{array}{l}\text { Singapor } \\
\text { e }\end{array}$ & 60,000 & $3,432,05$ & $5,850,343$ & 59,113 & 1,521 & 29 & 29 & 0.5 & 1.91 & 1.21 & 2.6 & 1 \\
\hline
\end{tabular}

*As of January 23, 2021, and March 13, 2021.

\section{Sources:}

1 Our World in Data, "Cumulative COVID-19 vaccinations doses," pp. https://ourworldindata.org/grapher/cumulativecovid-vaccinations?tab=table\&stackMode=absolute\&time=earliest..2021-01-23\&region=World. Accessed 23 January 2021 and 13 March 2021.

2 United Nations, Department of Economic and Social Affairs, Population Division (2019). Probabilistic Population Projections Rev. 1 based on the World Population Prospects 2019 Rev. 1: http://population.un.org/wpp/

3 World Health Organization, "Situation by Country, Territory \& Area," 14 January 2021. [Online]. Available: https://covid19.who.int/table. [Accessed 23 February 2021].

4 Author's estimates

It is imperative to consider that many countries are in group 1 or 2, not because of the number of cases and deaths are small, but because cases and deaths are underreported, as the surveillance systems are weak or there are limited resources to increase the number of COVID-19 tests for diagnosis and contact tracing. Another possibility is that the control measures that have some countries have applied are effective.

\section{Discussion}

As shown in Table 1, the observed mortality for many developing countries is lower than expected, possibly because of underreporting, limited COVID-19 testing, and sometimes political manipulation of the government's information to keep numbers low to send the message that the control measures are effective. Another reason is that many countries were isolated even before the COVID-19 pandemic. After all, they are not significant players in international trade exchange.

Another consideration that makes this problematic situation worst is the so-called "vaccine diplomacy" that in some instances forces some countries without the financial resources to buy vaccines or develop the technological capacities to manufacture vaccines, nor to establish economic or geopolitical agreements that benefit one side, and the other side is left at the mercy of making the sometimes-unfavorable decision to access vaccines. Some countries like China, India, European Union, Russia, and the United States will use vaccine diplomacy to maintain and strengthen their geopolitical spheres of influence around the world. Vaccine diplomacy could be an impediment for the COVID-19 Vaccine Global Coordination mechanism to play a strong role in both coordinating the distribution of vaccines and in purchasing negotiations, however, if this is the case in some situations, the Coordination could be very helpful in the internal vaccination process of the countries.

At present, all countries are playing a political game to send their population the signal that everything is under control and that vaccines for everyone are coming, or they already started vaccinating their people, without explaining that the amounts of vaccines they have access to are in quantities of crumbs; therefore, the impact of those vaccines will be hardly seen unless they begin to use an epidemiological approach like the proposed SMR to help identify where the result willbe higher with what is available.

With the above scenario and limited access to vaccines, the global community must take bold and unorthodox actions to reach at least $70 \%$ population coverage. In the first place, the response must be aimed at saving lives, that is, the application of vaccines in populations at higher risk and vulnerability, including the first-line responders, and then, the distribution should be based on the epidemiological analysis, which allows, in the medium term, to cut the transmission of the virus. Global and regional health governance mechanisms, including WHO, GAVI/COVAX, UNICEF, The Global Fund to Fight AIDS, TB, and Malaria, as well as global donors (e.g., Bill and Melinda Gates Foundation and USAID) and financial institutions such as the World Bank should adopt actions under the thought that this is the time to try bold innovation and unorthodox strategies based on a global, regional, and national geopoliticalepidemiological approach to address the challenges that represent limited access to vaccines. As suggested before, the international community must establish a COVID-19 Vaccine Global Coordination 
mechanism, led by WHO. With WHO acting as the COVID-19 Vaccine Global Coordinator in collaboration with GAVI/COVAX and UNICEF, they have the competencies to conduct an operation of this magnitude to bring together all global, regional, national stakeholders and donors to respond and move under one agreed strategy, identifying priorities and directing the limited amounts of vaccines to wherever place they will have the highest impact so they can contribute to bringing down the pandemic. WHO so far is the only global organization that has health operations in almost every country of the world, and although it needs to strengthen its technical and operational capacities, whether we like it or not, right now, it is the only multilateral agency that has the muscle to coordinate this complicated endeavor?

The COVID-19 Vaccine Global Coordination will face resistance at some point. However, if supported by evidence-based information, they will be more accepted if backed by robust epidemiological methods such as SMR. Whatever decisions are made regarding distributing vaccines and who gets the first shot, decisions will not be exempted from controversial ethical, political, economic, social, and equality access issues across countries, populations, and geographic areas. However, with the proposed approach, inequities can be minimized. Ultimately, the role of the COVID-19 Vaccine, Global Coordination will be to save as many lives as possible to reactivate economies and social interactions, as well as to begin to address the collateral health impact of health problems and public health interventions that were postponed due to the COVID pandemic, and the new health problems of this pandemic.

Many countries do not have a central coordination mechanism that leads the vaccination process against COVID-19 under a unifiedplan and strategies, leaving that responsibility to state or local authorities and sometimes multilateral organizations. This has resulted in "zillions of procedures" and different interpretation of the guidelines proposed by the national authority, including appropriate coordination of the various players responsible for vaccination, which leads to duplication of efforts, lack of technical support to implement programs, waste of financial and human resources, and in many instances, the local level lacks the needed competencies and or professionals to implement the vaccination the program has more effectively given the fact that there is a limited amount of vaccines, so they have to identify the highest priority groups and geographic areas, even under the recommended vaccination phases of the national health authority. Many developed and developing countries should rethink how vaccines are administered since there is no central command for vaccines' national coordination. When it exists, it is sometimes weak, leaving the COVID-19 vaccination procedures to the states or provinces discretion and resulting in different interpretations of the same recommended guidelines. Besides, many states or local levels do not have the competencies to implement the recommendation or conducting an epidemiological analysis of the situation to help them establish the highest priority groups and support the management of vaccination programs. Many of the counties' plans and strategies have been a political response to a pandemic that has surpassed global and country's response capacity to a public health event of unforeseeable proportion for our current times.

What is even more shocking is that despite the limited amounts of vaccines worldwide, many national vaccination plans do not consider all options such as vaccine access and availability (including delays in vaccine production and shipments), identification of priorities, logistics, cold chain networks, additional supplies needed to vaccine people and an army of trained vaccinators. The WHO recommended vaccination stages, and somehow the United States phases that many countries are using as a guide should be implemented under a stepwise approach, that is, if vaccines are scarce, each group of each stage must be disaggregated to create subgroups within the group to vaccinate those who are at higher risk, as vaccines become available, each phase/stage group can be expanded to cover other subgroups.

Limitations of this SMR analysis include that not all COVID-19 cases were diagnosed and not all the mortality has been reported; therefore, there is an underestimated number of cases and deaths, thus reducing the sensitivity of COVID-19 SMR priority the setting, and possibly due to a data lag, some of the missing cases and deaths will be reported during the first quarter of 2021. SMRs may change over time, as the implementation of control measures and vaccination increases can transform the pandemic trend in any given place; therefore, SMR estimates should be updated regularly. Furthermore, due to limited data access by age group data, SMR was not calculated using age standardization to obtain data on which age-specific group is more severely impacted by COVID-19 mortality.

From the authors' point of view, SMR should be used to prioritize COVID-19 vaccine access because of the limited number of them worldwide, leaving at this point most countries of the world (developed and developing) with small numbers of vaccines that hardly will contribute to control, mitigate or suppress the pandemic, that is why those limited number of vaccines should be targeted to those geographic and the high-risk group where the impact will be higher. The global community and countries must accept that producing vaccines takes time and requires financial resources for their production and acquisition and their distribution and administration with the support of a robust logistic program globally and nationally. It is not enough to waive intellectual property rights. We also need international cooperation for strengthening laboratory vaccine production in those countries that may have the capacity as the new COVID-19 vaccine manufacturing is a complex and highly skilled task. [15] Finally, everyone must recognize that it is not enough to have vaccines without programs with the necessary resources to undertake the vaccination process. The enormous effort to vaccinate everyone is as expensive and complicated as procuring vaccines. It is not enough to have high vaccination coverage in the 
developed world. This does not guarantee that in countries with low vaccination coverage against COVID-19, the strains cannot mutate and create new variants with greater pathogenicity, virulence, and

\section{Declarations}

Ethics approval and consent to participate: Ethical approval not applicable. All authors have consent to participate in this review/research

Consent for publication: Not applicable.

Availability of data and material: Database is available upon request.

\section{References}

1. J. Michaud, J. Kates (2020) "The Dangers of Vaccine Disillusionment: A Viable Immunization is Good News, bu Reality Won't Match Expectations for Many Months," Foreign Affairs.

2. J. Ravelo (2021) "Tedros calls out "me-first" approach to COVID19 vaccines: 'This is wrong'," Devex.

3. F. G. de Cosio (2020) "The Complexities of Making the COVID19 Vaccine Available Everywhere: This is a time for action, not complacency," Unpublised.

4. J. L. Ravelo, "COVID-19 vaccines are a scientific feat -but lowerinconme nations are sitll fighting for equity," 23 December 2020.

5. Lancet, "Global governance fore COVID-19 vaccines," Lancet. 395(1883)

6. Green A (2021) "Middle-income countries are caught in a COVID-19 financing gap." Devex.

7. M. Singh, L. Gambino, J. Walters, M. Belam (2021) "Biden pleadges all US adluts will beeligible for vaccinesby 1 May in pandejic anniversary address," The Guardian.

8. Office of the United States Trade Representative., (2021) "Statement from Ambassador Katherined Tai on the Covid-19 Trips Waiver." lethality. No one can be left behind; otherwise, the world will not be safe.

Competing interests: Authors have no competing interest

Funding: This review/research received no specific grant fromany funding agency in the public, commercial, or not-for-profit sectors.

Authors' contributions: All authors contributed to the preparation of this article.

9. B. Mueller, R. Robbins, L. Chutel (2021) "AstraZeneca's Vaccine Does Not Work Well Against Virus Variant in South Africa," The New York Times.

10. G. A. a. G. E. D. Dever, "Identifying problems, determining priorities," in Epidemiology in health services management, Gaithersburg, Aspen Publishers, 1984, pp. 109-115.

11. D. J. Muscatello, P. B. Mclntyre (2020) "Comparing mortalities of the first wave of coronavirus diseae 2019 (COVID-19) and the 1918=19 winter pandemic influenza wave in the USA," International Journal of Epidemiology. 49(6): 2089-2091.

12. United Nations, Department of Economic and Social , "Probabilistic Population Projections Rev. 1 based on the World Population Prospects 2019 Rev. 1," United Nations, 2019.

13. World Health Organization, "Situation by Country, Territory \& Area," 14 January 2021.

14. Our World in Data, "Cumulative COVID-19 vaccinations doses," pp. 23 January 2021.

15. P. J. Hotez, M. E. Bottazzi, Y. Prashant (2021) "Producing a Vaccine Requires More Than a Patent Intellectual Property Is Just One Piece of an Elaborate Process," Foreign Affairs. 